\title{
Factors Influencing Internal Shariah Audit Effectiveness: Evidence From Bahrain
}

\author{
Azam Abdelhakeem Khalid Ahmed ${ }^{1} \&$ Adel M. Sarea ${ }^{2}$ \\ ${ }^{1}$ Department of Accounting and Finance, Faculty of Management and Economics, Universiti Pendidikan Sultan Idris, \\ Perak, Malaysia \\ ${ }^{2}$ College of Business, Ahlia University, Bahrain \\ Correspondence: Azam Abdelhakeem Khalid Ahmed, Department of Accounting and Finance, Faculty of \\ Management and Economics, Universiti Pendidikan Sultan Idris, Perak, Malaysia.
}

Received: July 31, 2019

doi:10.5430/ijfr.v10n6p196
Accepted: September 5, 2019

Online Published: September 8, 2019

URL: https://doi.org/10.5430/ijfr.v10n6p196

\begin{abstract}
It is this research's objective to analyze factors that cause an effective internal Shariah audit among the Islamic Financial Institutions (IFIs) in Bahrain. The questionnaire method has been employed to examine the said topic. The questionnaire's primary source of information was the Accounting and Auditing Organizations for Islamic Financial Institutions (AAOIFI) Governance Standards. Meanwhile, the respondents are consisted of 52 IFIs' head of internal Shariah audit department. These IFIs are registered with the Central Bank of Bahrain. To analyze those relationships the structural equation method (SEM) via SmarPLS3.0 has been adopted. The study has found that the effective execution of internal Shariah audit is positively linked with the competency and performance of internal Shariah audit. Meanwhile, the other two variables, i.e. being independent and Shariah supervisory board have been discovered to be positively related with internal Shariah audit effectiveness. Nonetheless, there is no significant contribution. Overall, all the variables contribute $63.2 \%$ to IFIs' internal Shariah audit effectiveness. The regulatory and professional bodies may benefit from this study in their assessment of factors that result in a successful and meaningful internal auditing of Shariah matters.
\end{abstract}

Keywords: internal Shariah audit, effectiveness, independence, competency, Shariah supervisory board, Bahrain

\section{Research Overview}

The history of banking industry of the Cooperation Council for the Arab States of the Gulf region (Gulf Cooperation Countries (GCC)) can be traced back to 1918 when the first bank in Bahrain was established by the British (Sarea and Hanefah, 2013). Towards ensuring the growth of sector of the Islamic banking and finance, the Kingdom of Bahrain has placed the nation as a center for various Islamic financial entities; whereby these include the, the General Council for Islamic Banks and Financial Institutions, the Accounting and Auditing Organization for Islamic Financial Institutions (AAOIFI), the Islamic International Rating Agency (IIRA), and International Islamic Financial Market (IIFM) (Sarea, 2012).

Due to rapid growth, the industry could not fulfil the demand of IFIs for experts (Iqbal and Molyneux, 2005). Most of the experts have failed to give a good advice or supervise IFI transactions as they do not have sufficient time to acquire the necessary experience. The experience of internal Shariah auditor is quite inadequate in certain IFIs. This will directly impact the effectiveness of these IFIs' internal Shariah auditors. Thus, to increase the number of trained professional auditors, certifications called the Certified Islamic Professional Accountant (CIPA) and Certified Shariah Advisor and Auditor (CSAA) are being offered by AAOIFI. To attain these certifications, despite its good intention, there are no preconditions for the registering of the courses. The students of these programs are those involved in banking and finance's Shariah compliance and review, as well as professionals and personnel who are interested in the areas of finance, audit and accounting (Othman et al., 2015). This signifies that everyone can apply, hence affecting the goals of the programs. This is because the applicants of the programs do not have to possess certain requirement for enrollment.

In general, Shariah compliance has two types: (i) ex-ante compliance, and (ii) ex-post compliance. Ex-ante Shariah compliance is when SSB directs, reviews, and supervises IFIs' actions; whereby these are done to ensure that the 
rules and principles of Shariah are adhered to. The activities encompass the IFIs' compliance with rules and guidelines of Shariah during the contract and agreement's development, transaction processes, contract's closing, up to the execution of contract's terms, as well as liquidation. Whereas Ex-post Shariah compliance processes requires thorough and comprehensive internal Shariah audits in order to review and check the transactions that took place after the execution of the contracts. The ex-post Shariah compliance is to perform the random samples of completed transactions to ensure that these transactions conform to Shariah rules and principles. Currently, not many IFIs adopt the processes of ex-post Shariah compliance (Rahman, 2011).

The processes of ex-post Shariah compliance demand the internal Shariah audit be done thoroughly and comprehensively in the checking and reviewing of transactions that happened after a contract's execution. Random samples are to be taken from completed transactions so that compliance to Shariah's rules and principles can be ascertained. This activity needs to be undertaken as the auditors have to make a report to the management (Rahman, 2008). Nonetheless, there is a shortcoming in ex-post Shariah compliance when there is deficiency in work quality.

In Bahrain, there are indications that problems occurred due to the lack of internal Shariah audit effectiveness. Despite the assurance given by the IFIs' SSBs that there is compliance with Shariah, there are still lack of, and poorly conducted complete audit or review processes on Shariah legal documents, agreements and operation (Rahman, 2008). Similarly, internal Shariah audit's lack of effectiveness can be a result of the lack of independence, competency and the performance in conceiving and executing tasks as well as communication of results; whereby all these elements have been measured by previous studies (Ahmad, H., Othman, R., \& Josef, K., 2009; Al-Twaijry et al., 2003; Alzeban, A., \& Gwilliam, D., 2014; Arena \& Azzone, 2009; Mihret \& Yisamaw, 2007).

Based on the annual reports of IFIs from 2010 to 2014 (taken from websites), the SSB reports contained therein indicate the absence of these elements. The internal Shariah audit had failed to perform its duty whereby three SSB reports had been found to be not in compliance with Shariah law, especially in Islamic banks. This non- adherence may have a profound effect impact on the IFIs' income and profit. In the long term, this violation may negatively impact the shareholders' perception of Islamic financial practice; whereby resulting in a significant deficit of trust and credibility. In view that majority of the customers use Islamic financial institution for religious purposes, non-compliance can cause reputation risk such as interests, impermissible earnings and impure earning. Hence, rendering Islamic financial sector to be vulnerable to being unsteady and fail (Qattan, 2003).

\section{Literature Review: Need for the Study}

\subsection{Internal Shariah Audit Effectiveness}

Past research on Shariah audit has examined the requirement and difficulties (Rahman, 2008), academics and practitioners' perception towards Shariah audit (Mulany, 2008), other research of IFIs' Shariah audit operations concentrates on audit magnitude, competency, and practices; as well as prevailing framework in conducting Shariah audit (Kasim et al., 2009; Yahya \& Mahzan, 2012). Nonetheless, the effectiveness of Shariah audit is not being widely covered as opposed to external and internal audit in traditional banking system. Nowadays, the review process and audit on Shariah compliance are internally conducted. The review on literature of an effective internal Shariah audit is from past research such as Badara \& Saidin (2014); Arena \& Azzone (2009; Ahmad (2009); Mihret \& Yismaw (2007); Endaya \& Hanefah (2013). Shariah auditors' professionalism (Najeed and Ibrahim, 2014), conceptualization of the responsibilities and guidelines of Shariah auditors (Othman, et al., 2015) and Shariah-compliant audit framework (Shafii et al., 2015).

From literature review, the authors have not found any studies that relate to the examination of factors that cause Islamic bank's internal Shariah audit to be effective. Attributes such as the auditors' interaction capability and dedication as well as the backing given by audit committee and BOD, the audit's integrity and performance, efficiency, competent audit, the auditor's comprehension of business operation and industry, and independent auditors have been discovered to cause a successful audit (Nasibah et al., 2009). The internal Shariah audit needs to show its effectiveness through the utilization of performance measuring system that relates to the main shareholders' expectation. An effective internal Shariah audit can become a value added or outcome of internal Shariah audit. The most used effectiveness measure encompasses planned audit completion, completion of audit within stipulated time frame, as well as acknowledgement and implementation of the internal audit's recommendations (Soh and Martinov-Bennie, 2011).

Due to the scarcity of studies on being an effective internal Shariah auditor, the researchers have measured their effectiveness in terms of the capability to recognize activities that are non-Shariah compliant in the organizations' policies and procedures, and their contribution to Bahrain's IFIs. 


\subsection{Characteristics of Internal Shariah Audit}

Review on literature in regard to the attributes of internal Shariah audit shows that an independent, competent internal Shariah audit as well as the performance of planning, execution and communication of results of the audit result in effective auditing. The characteristics of IFIs' audit activities are similar to conventional audit, but it may be adapted to suit the features of Islam financial products and services (Yahya and Mahzan, 2012). The general goal of this study is to conduct an in-depth examination on how effective is the internal Shariah audit departments of Bahrain's IFIs. Additionally, it is also to gauge the degree of comprehension of the internal Shariah audit's personnel.

To conclude, based on past research and AAOIFI benchmarks, the researchers have recognized the three important factors affecting the effectiveness of internal Shariah audit. Those factors are independent, competent and performance. It has been emphasized by the AAOIFI (2010) on the significance of internal Shariah audit's goals; review; freedom and fairness; proficient professionalism; magnitude, supervision, assurance of quality; and control system's attributes. Thus, this study has conceptualized internal Shariah audit system to encompass three factors. The first is independence, a vital attribute to be included for an effective internal Shariah audit. The second, competence is considered in terms of continuous learning, knowledge in Shariah and accounts, training, capability and experience. Third, performance where it encompasses planning of documentation, planning and executing of tasks, as well as communicating results of the audit. This is consistent with the benchmarks of AAOIFI and past research. Therefore, this study proposes that the three factors, i.e. independent, competent and performance as the vital attributes that will lead to a meaningful and successful audit by internal Shariah auditors in Bahrain's IFIs.

\section{Hypotheses Development}

\subsection{Independent Internal Shariah Audit}

The auditors of Shariah audit are often placed in the internal audit department. It is their duty to discover and measure the degree of fulfilment of the IFI with Islamic laws and regulations, Fatwas, and directives given by the SSB. The main goal of internal Shariah audit is ensuring the IFI's management executes its responsibility in the implementation of matters related to the Islamic laws as stipulated by the IFI's SSB (AAOIFI, 2010). Therefore, it is proposed that there is a requirement to having permanent independent auditors in IFIs (Kassim et al., 2009). Those internal auditors should have independent mind. They must maintain high degree of freedom in gaining the confidence of their reports' users (Rahman, 2011).

The study done by Al-Twaijry et al. (2003) mentions that unconstrained inspection to documents and unlimited probing capacity are vital aspects of being an independent and effective internal auditor. Additionally, Getie Mihret and Wondim Yismaw (2007) state that in attaining a meaningful audit, the auditors must have a complete accessibility to transactions, documents and properties. They are also to be given a cooperation by the auditees. Therefore, the internal Shariah auditors have to be adequately free from the auditees in conducting an objective and interference-free audit. Consequently, this signifies that independence is the key word for a meaningful and successful internal Shariah audit. Based on the above, the following is hypothesis is proposed:

H1: Internal Shariah audit effectiveness is positively influenced by independent internal Shariah audit.

\subsection{Competent Internal Shariah Audit}

It has been argued by Shafii et al. (2015) that Shariah auditors are to have the knowledge and experience in auditing IFIs. It is recommended that every Shariah auditor to have a Shariah certification. Additionally, Hameed and Mulyany (2009) highlight on the significance of Shariah auditors of having an established and standardized qualification as well as competence certification. Moreover, the auditors are also to possess the certifications of both Shariah audit as well as the accounts and audit areas.

Ali (2007) has analyzed the importance of internal audit in Malaysian public sector. He finds that inadequacies of trained personnel in terms of education, experience and expertise of internal audit do have a negative impact on an internal auditor's performance. Thus, he proposes that training is a vital element to improving this situation. Based on past research, it has been proposed that knowledge and education impact the effectiveness of Shariah internal auditors. Therefore, we propose that an effective internal Shariah audit is positively being affected by competence. The following hypothesis is proposed:

H2: Internal Shariah audit effectiveness is positively being influenced by competent internal Shariah auditor. 


\subsection{Internal Shariah Audit's Work Performance}

It is expected that the internal Shariah auditors to execute their jobs consistent with the benchmarks of auditing. They need to plan and execute their tasks properly, as well as communicate the outcomes of their findings to relevant parties.

Khan (1982) mentions that the area of Shariah auditing framework is of much larger magnitude than the traditional audit, i.e. from the conventional notions of attest and authority, to the reporting of multiple aspects of social and economy of business entities. Also, some financial statements' users feel that the auditors must make remarks on management's performance in addition to their current tasks of financial reporting (Goodwin-Stewart and Kent, 2006). It is the aim of Islamic bodies and IFIs to make the magnitude of Shariah audit greater, and this is a challenge. The challenge may be posed upon the policy makers and the senior managers who have to confront enthusiastic auditors and of various beliefs and practices. It is envisioned that Shariah audit to encompass 'social behavior' and organizational performance including that of relationships with all stakeholders (Hisham and Nor Khadijah, 2012). Also, (Hisham and Nor Khadijah, 2012) state that Shariah audit also needs to cover the computation and payment of Zakah and this is concurred by (Hood and Bucheery, 1999; Ratana and Hameed, 2009).

The success of Shariah audit is dependent upon Shariah counselors, as well as the Shariah Supervisory Board (SSB). This notion is concurred by Rahman (2008) whereby he mentions that the sector of Islamic finance is not adopting the Shariah audit systematically, that is, a structured probing is yet to be implemented in ensuring full adherence to Islamic guidelines. As such, the operations of IFIs should also be under the purview of Shariah audit where this includes policies and procedures, product guides, operation processes, and agreements. A review on organizational structure by the Shariah audit also needs to be undertaken in ensuring the feasibility of implementing Shariah-compliant activities.

Therefore, it is contended that highlighting on the significance of internal Shariah audit's performance will positively result in an effective internal Shariah audit. Hence, the following hypothesis is:

H3: Internal Shariah audit effectiveness is positively influenced by work performance of internal Shariah auditors.

\subsection{Quality of Shariah Supervisory Board}

Currently, SSB undertakes the responsibility of Shariah auditors in certifying the Shariah reports for financial statements' users (Karim, 1990). These reports are a vital part of the IFIs' annual report. The report is an additional task to their primary tasks of giving advice and supervising Shariah-compliant products and services. Primarily, SSB extends over five key areas: certifies recognized financial instruments through Fatwas (ex-ante Shariah audit), verifies that transactions conformed to fatwas (ex-post Shariah audit), computes and pays Zakah, as well as counsel on the disposal of non-Shariah compliant earnings and the allocation of earnings or expenditures among stockholders and investment account holders (Grais and Pellegrini, 2006). Therefore, to perform this supervisory role, a good SSB is a must for every IFI.

In addition to having an internal audit charter, a good SSB is characterized by its degree of independence as well as its composition, expertise and size. Similar to the traditional bank's audit committee as part of corporate governance, it is gaining its prominence particularly when the members of committee are those of high integrity with certain independence level, qualification, knowledge and experience (Alkdai and Hanefah, 2012, Haron et al., 2005). Also, in addition to an audit committee's vital roles of supervising, ensuring valid financial statements and corporate responsibility, it also serves as a supervision tool. This is because the audit committee controls the linkages among various aspects in an organization (Turley and Zaman, 2007).

The corporate governance of Islamic model for business entities is based on Shariah rules and guidelines; and the IFIs' unique characteristics must be verified in improving their corporate governance mechanisms. Hence, the most vital difference between Islamic and traditional banking systems is the SSB (Grais and Pellegrini, 2006, Farook et al., 2011). As a result, SSB can only be successful once it attained its establishment's goals, and that encompass the enhancement of the corporate Shariah governance of the institution. Therefore, for this study's purpose, SSB's quality is about the capability of the SSB in achieving its goals as well as enhancing the elements affecting internal Shariah audit effectiveness (i.e. independent, competent, and performance of internal Shariah audit).

For an internal audit that is independent and competent, it is posited by Davies (2009) that the roles of Head of internal audit and internal audit unit must be enhanced by the audit committee. This is done to achieve a greater degree of freedom and fairness, education and experience. As such, the impact of SSB in the linkages of these elements with internal Shariah audit effectiveness is analyzed by this study. The hypotheses are as the followings: 
H4: The link between independent internal Shariah auditors and internal Shariah audit effectiveness is moderated by SSB.

H5: The link between competent internal Shariah auditors and internal Shariah audit effectiveness is moderated by SSB.

H6: The link between performance of internal Shariah auditors and internal Shariah audit effectiveness is moderated by SSB.

\section{Research Methodology}

All the IFIs are as per the listing of Central Bank of Bahrain (CBB); and they are this study's population. As of 31st December, 2015, there were 52 registered IFIs; and classified as follows: 25 Islamic banks, 12 Islamic insurance companies (Takaful), 7 Islamic investment institutions, 3 Islamic finance institutions and 5 Islamic windows. In view of the small population, this study had utilized the census sampling method in which the data were collected from everyone. It is noted that every IFI has its own Head of internal Shariah audit department. The main aim of this study is to analyze how effective is internal Shariah audit department among Bahrain's IFIs. The data were gathered by utilizing the questionnaire survey method. This method is recommended by Fowler (2009) because it is inexpensive, needs the lowest number of personnel and resources, and provide the respondents an ample time to answer. All questions which ranged from (1) highly disagree to (5) highly agree, were in accordance to 5-point Likert scale. Hence, the data are considered as ordinal data. This study interprets the effectiveness of internal Shariah audit as the results of auditing done. Here, the performance of internal Shariah audit will be calculated through the examination on the magnitude of major findings, achievement of planning, acceptance of recommendation, and execution of rectifications. Internal audit is considered meaningful if it brings the desired results to the entities (Getie Mihret and Wondim Yismaw, 2007).

To conduct the measurements, questionnaires were given to the respondents, i.e. the Heads of internal Shariah audit. The survey questions consisted a mixed of inquiries in accordance to AAOIFI benchmarks (2010). For the internal Shariah audit's independence, it was measured based on AAOIFI benchmarks (2010) and consisted of 6 items. The questions covered organizational position, extent of management's direct interaction, conflict of interest, unlimited access, fairness and maintenance. As for competency, it measured the extent of the qualification of the auditors in causing a successful and meaningful internal Shariah audit. It was measured by 6 items such as educational attainment, professional certifications, due professional care, professional experience in internal Shariah audit, as well as their training and skills. These measurements were also formulated in accordance to AAOIFI benchmarks (2010). Meanwhile, work performance is about capturing the information of whether the tasks of internal Shariah audit concentrate on fulfilment of Islamic law or financial reports. The performance that is of good quality ensures a quality work performance. Past studies state that work performance encompasses audit procedures' comprehensiveness and quality, documentation, planning, magnitude and reporting (AAOIFI, 2010). For this study, work performance of internal Shariah audit was measured from three aspects; namely planning and performing the tasks and communicating outcomes. These measurements were formulated based on AAOIFI benchmarks (2010). The analyses of the survey were conducted using SPSS Version 24, and SmartPLS 3.0 was utilized to examine the linkages of the constructs through partial least square (PLS) analysis.

\section{Research Analysis and Results}

\subsection{Respondents' Demographic Profile}

Table 5.1 shows the demographics of the IFIs being surveyed; where 25 (48.15) were Islamic banks, $12(23.1 \%)$ Islamic takaful companies, 7 (13.5\%) Islamic investment institutions, 5 (9.6\%) with Islamic window, and $3(5.8 \%)$ Islamic finance companies. As for the descriptive statistics, $38(73.1 \%)$ of the respondents were Heads of internal Shariah audit department, 9 (17.3\%) were assistant Shariah Auditors and 5 (9.6\%) were senior Shariah auditors. Hence, indicating that most of the respondents were Heads of internal Shariah audit. As for their educational attainment, most of them 28 (53.8\%) were degree holders, and others $17(32.7 \%)$ possessed diplomas. Hence, indicating that most of them were with post-secondary qualification. In terms of professional certification, 19 (36.5\%) of them were CPA holders, $12(23.1 \%)$ ACCA, $9(17.3 \%)$ CIPA, as well as 6 respondents for each CIA and CSAA (11.5\% of the total respondents). In terms of professional experience, $23(44.2 \%)$ were with not more than 3 years, $12(23.1 \%)$ with experience from 3 to 6 years, and $3(5.8 \%)$ had experience of 6 to 15 years. Thus, showing that most respondents did not possess adequate professional experience. For the function and daily reporting of internal Shariah audit, $40(76.9 \%)$ of the respondents agreed that they report to SSB, $28(53.8 \%)$ reported daily to the CEO and $6(11.5 \%)$ reported to Audit and governance committee (AGC). 
The statistics on availability and written internal Shariah audit's charter are at $46(88.5 \%)$ and $41(78.8 \%)$, respectively. Meanwhile, 45 (86.5\%) of the charters were SSB-approved. Finally, the size's mean of internal Shariah audit department is 4 staff. This is due to the small scale of the IFIs' operation. Additionally, 3 SSB members were also serving other IFIs due to the inadequacy of such competent professionals in the nation. Therefore, majority of the SSB members were cross-members. The demographic data are illustrated by Table 1 below.

Table 1. Respondents' demographic profile

\begin{tabular}{|c|c|c|c|}
\hline Demographic & Category & Frequency & Percentage $(\%)$ \\
\hline \multirow[t]{6}{*}{ Type of IFI } & Islamic bank & 25 & 48.1 \\
\hline & Islamic Insurance & 12 & 23.1 \\
\hline & Islamic Investment & 7 & 13.5 \\
\hline & Islamic Finance & 3 & 5.8 \\
\hline & Islamic Window & 5 & 9.6 \\
\hline & Total & 52 & 100.0 \\
\hline \multirow[t]{4}{*}{ Position } & Senior Shariah Auditor & 5 & 9.6 \\
\hline & Assistant Shariah Auditor & 9 & 17.3 \\
\hline & Head of Internal Shariah Audit & 38 & 73.1 \\
\hline & Total & 52 & 100.0 \\
\hline \multirow[t]{5}{*}{ Educational Qualifications } & Diploma & 17 & 32.7 \\
\hline & Degree & 28 & 53.8 \\
\hline & Master & 1 & 1.9 \\
\hline & $\mathrm{PhD}$ & 6 & 11.5 \\
\hline & Total & 52 & 100.0 \\
\hline \multirow[t]{6}{*}{ Professional Qualifications } & $\mathrm{CPA}$ & 19 & 36.5 \\
\hline & ACCA & 12 & 23.1 \\
\hline & CIA & 6 & 11.5 \\
\hline & CIPA & 9 & 17.3 \\
\hline & CSAA & 6 & 11.5 \\
\hline & Total & 52 & 100.0 \\
\hline \multirow[t]{7}{*}{ Working Experience } & Less than 3 years & 23 & 44.2 \\
\hline & $3-6$ years & 12 & 23.1 \\
\hline & 6-9 years & 3 & 5.8 \\
\hline & $9-12$ years & 3 & 5.8 \\
\hline & $12-15$ years & 3 & 5.8 \\
\hline & Above 15 & 8 & 15.4 \\
\hline & Total & 52 & 100.0 \\
\hline \multirow[t]{4}{*}{ Functional report } & AGC & 6 & 11.5 \\
\hline & CEO & 6 & 11.5 \\
\hline & SSB & 40 & 76.9 \\
\hline & Total & 52 & 100.0 \\
\hline \multirow[t]{4}{*}{ Daily basis report } & AGC & 8 & 15.4 \\
\hline & CEO & 28 & 53.8 \\
\hline & SSB & 16 & 30.8 \\
\hline & Total & 52 & 100.0 \\
\hline \multirow[t]{2}{*}{ ISA Charter } & Yes & 46 & 88.5 \\
\hline & No & 6 & 11.5 \\
\hline
\end{tabular}




\begin{tabular}{llll}
\hline & Total & 52 & 100.0 \\
\hline Written Charter & Yes & 41 & 78.8 \\
\hline & No & 11 & 21.2 \\
\hline Sotal & 52 & 100.0 \\
\hline & Yes & 45 & 86.5 \\
\hline & No & 7 & 13.5 \\
\hline & Total & 52 & 100.0
\end{tabular}

\subsection{Measurement Model}

The measurement model was analyzed to discover the measurement items' validity and reliability. The next sub-section will do in-depth analyses on individual loadings, internal composite reliability, and discriminant validity. The extent of the measured variables in measuring what they are supposed to measure analyzed through construct validity. It has to be in accordance to highly reliable theoretical measure (Hair et al., 2011). Meanwhile, reliability is about being consistent; and construct validity is estimated through convergent validity and discriminant validity (Hair et al., 2010).

Convergent validity is about the degree of a measure correlating positively with another measure of similar construct. For construct validity, the Average Variance Extracted (AVE) is used to calculate convergent validity at construct level (Hair et al., 2010). To confirm the latent variable is explaining greater than half of its indicator variance, it has been suggested by Hair et al. (2011) that an AVE value of 0.5 and above has to be attained. This study has found that all the AVEs' values are greater than the threshold value. As for item loading, the cut-off value is 0.708 and certain items did not attain this value. Hair et al. (2013) suggest that indicators with outer loading of 0.4 to 0.7 have to be removed should their absence causes improvement in AVE and CR. Composite reliability (CR) estimates the consistency of the measuring items, and this method suits PLS-SEM better than Cronbach's Alpha (Hair et al., 2011). All constructs' CRs are satisfactory with values exceeding 0.7. As such, convergent validity, individual loadings, internal composite reliability, and discriminant validity are supported (Nunnally and Bernstein, 1994). Table 2 illustrates the measurement model.

Table 2. Measurement Model

\begin{tabular}{lllll}
\hline Construct & Item & Loading & AVE & CR \\
\hline Independence & ISAI1 & 0.652 & 0.520 & 0.864 \\
\hline & ISAI2 & 0.828 & & \\
\hline & ISAI3 & 0.634 & & \\
\hline & ISAI4 & 0.619 & & \\
\hline ISAI5 & 0.900 & & \\
\hline Competence & ISAI6 & 0.645 & & 0.779 \\
\hline ISAC3 & 0.623 & 0.544 & \\
\hline Effective & ISAC4 & 0.831 & & \\
\hline & ISAC5 & 0.746 & & \\
\hline & ISAE1 & 0.730 & 0.566 & \\
\hline ISAE3 & 0.726 & & \\
\hline ISAE5 & 0.798 & & \\
\hline Performance & ISAE6 & 0.754 & & \\
\hline & ISAWP2 & 0.755 & 0.517 & 0.810 \\
\hline ISAWP7 & 0.713 & & \\
\hline & ISAWP13 & 0.762 & & \\
\hline & ISAWP14 & 0.639 & &
\end{tabular}




\begin{tabular}{lllll}
\hline Supervise & SSB1 & 0.787 & 0.542 & 0.855 \\
\hline & SSB2 & 0.796 & & \\
\hline SSB3 & 0.721 & & \\
\hline SSB5 & 0.690 & & \\
\hline SSB6 & 0.680 & & \\
\hline
\end{tabular}

Discriminant validity is the degree of a construct being genuinely and completely distinct from the others (Hair et al., 2013). Consistently, discriminant validity with a high value illustrates that the construct is distinctive and does not reflect the situation of other constructs. Numerous methods can be used to calculate discriminant validity. However, the more accurate method is by comparing the AVE's square root with the latent variable's correlation. Here, each construct's AVE square root has to be more substantial than the highest correlation with other constructs (Fornell and Larcker, 1981). As such, as illustrated by Table 3, discriminant validity is confirmed.

Table 3. Discriminant validity

\begin{tabular}{llllll}
\hline & ISAC & ISAE & ISAI & ISAWP & SSB \\
\hline ISAC & $\mathbf{0 . 7 3 8}$ & & & & \\
ISAE & 0.549 & $\mathbf{0 . 7 5 4}$ & & & \\
ISAI & 0.663 & 0.634 & $\mathbf{0 . 7 2 1}$ & & \\
ISAWP & 0.385 & 0.670 & 0.563 & $\mathbf{0 . 7 1 9}$ & \\
SSB & 0.583 & 0.675 & 0.718 & 0.707 & $\mathbf{0 . 7 3 6}$ \\
\hline
\end{tabular}

Diagonals in (bold) represent the squared root of AVE; while the others represent the correlation

ISAI: Internal Shariah Audit Independence

ISAC: Internal Shariah Audit Competency

ISAE: Internal Shariah Audit Effectiveness

ISAWP: Internal Shariah Audit Work Performance

SSB: Shariah Supervisory Board

\subsection{Assessment of Structural Model Direct Effect}

The analysis on the measurement model is done prior to structural modelling. The analyses are conducted to examine the linkages among the variables (Duarte and Raposo, 2010). In the structural model, the variables' relationship paths variables had been calculated. This is accompanied by the bootstrapping analysis to examine the extent of the path coefficients. This analysis is considered non-parametric to statistical inference where distributional assumptions are not made (Sharma \& Kin, 2013). For this study, 5000-resampling method had been used in testing the regression coefficient's significance. This is the often recommended procedure for bootstrapping in estimating parameters (Chin et al., 2003).

The findings indicate that all constructs have positive relationship with internal Shariah audit effectiveness (ISAE); whereby internal Shariah audit independence (ISAI) shows $(\beta=0.157, p<0.01)$, internal Shariah audit competency (ISAC) shows $(\beta=0.201, \mathrm{p}<0.01)$, and internal Shariah audit work performance (ISAWP) shows $(\beta=0.391, \mathrm{p}<0.01)$. Moreover, SSB quality is positively linked with ISAE, $(\beta=0.161, \mathrm{p}<0.01)$. Meanwhile, ISAI is positively and insignificantly linked with ISAE. As such, hypothesis $\mathrm{H} 1$ is not supported, but hypotheses $\mathrm{H} 2$ and $\mathrm{H} 3$ are supported. The findings are presented in Figure 1 and Table 4 . The $\mathrm{R}^{2}$ of ISAE is 0.580 , suggesting that $58 \%$ of ISAE's variance is explained by SSB, independence, competence, and work performance. Item loadings of all items should exceed 0.708 , but some of them are below that value. Hair et al. (2013) propose that those with outer loading from 0.4 to 0.7 be removed should their absence causes average variance extracted (AVE) and composite reliability (CR) to exceed cut-off value. 


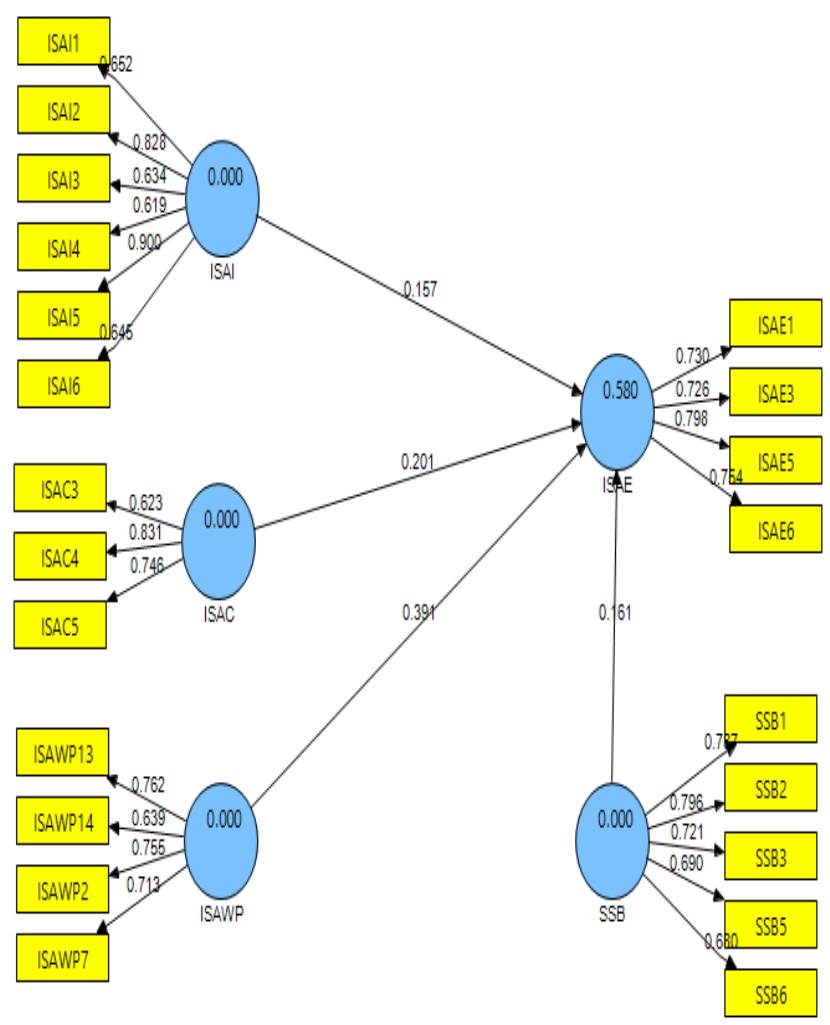

Figure 1. Structural model

ISAI: Internal Shariah Audit Independence

ISAC: Internal Shariah Audit Competency

ISAWP: Internal Shariah Audit Work Performance

ISAE: Internal Shariah Audit Effectiveness

SSB: Shariah Supervisory Board

Table 4. Hypothesis testing for directs effect

\begin{tabular}{llllll}
\hline Hypothesis & Linkage & Std. Beta & Std. Error & t-value & Result \\
\hline H1 & ISAI -> ISAE & 0.157 & 0.181 & 0.871 & Unsupported \\
\hline H2 & ISAC -> ISAE & 0.201 & 0.126 & $1.692^{* *}$ & Supported \\
\hline H3 & ISAWP -> ISAE & 0.391 & 0.157 & $2.492^{* *}$ & Supported \\
\hline
\end{tabular}

** $\mathrm{p}<0.01, * \mathrm{p}<0.05$

ISAI: Internal Shariah Audit Independence

ISAC: Internal Shariah Audit Competency

ISAWP: Internal Shariah Audit Work Performance

ISAE: Internal Shariah Audit Effectiveness

SSB: Shariah Supervisory Board

\subsection{Moderating Effect}

PLS was used to analyze the moderator's impact. As proposed by Chin et al., (2003), the product indicator method had been utilized. This is to observe the moderator role of SSB in the relationships between the characteristics being 
examined (i.e. independent, competent and work performance), and internal Shariah audit effectiveness. As such, a bootstrap with 5000-resampling was conducted (refer Figure 5.2) to test their interaction effects. Table 5.5 reveals that SSB quality does not moderate the relationships of the examined characteristics and internal Shariah audit effectiveness.

Table 5. Moderator analysis's findings

\begin{tabular}{llllll}
\hline Hypothesis & Linkage & Std. Beta & Std. Error & t-value & Result \\
\hline H1 & ISAI -> ISAE & 0.092 & 0.184 & 0.502 & Unsupported \\
\hline H2 & ISAC -> ISAE & 0.226 & 0.138 & $1.655^{* *}$ & Supported \\
\hline H3 & ISAWP -> ISAE & 0.421 & 0.166 & $2.540^{* *}$ & Supported \\
\hline H4 & ISAI * SSB -> ISAE & -0.087 & 0.343 & 0.253 & Unsupported \\
\hline H5 & ISAC * SSB -> ISAE & -0.345 & 0.266 & 1.294 & Unsupported \\
\hline H6 & ISAWP * SSB -> ISAE & 0.207 & 0.296 & 0.700 & Unsupported \\
$* * \mathrm{p}<0.01$ & & & & &
\end{tabular}

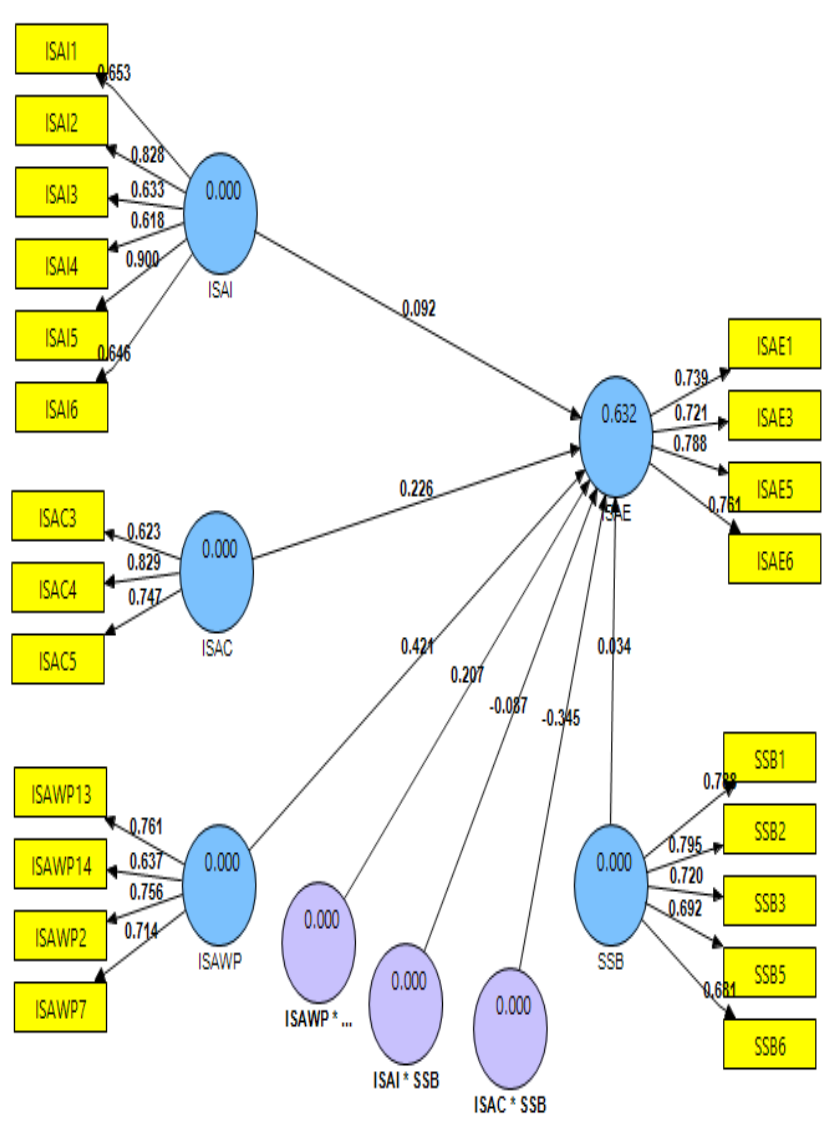

Figure 2. The $\mathrm{R}^{2}$ main effect model

ISAI: Internal Shariah Audit Independence

ISAC: Internal Shariah Audit Competency

ISAWP: Internal Shariah Audit Work Performance

ISAE: Internal Shariah Audit Effectiveness

SSB: Shariah Supervisory Board 
The changes in $\mathrm{R}^{2}$ is also a vital issue in moderation analysis. The $\mathrm{R}^{2}$ in the main effect model is 0.580 . Meanwhile, the interaction effect model's $\mathrm{R}^{2}$ is 0.632 . With $\mathrm{R}^{2}$ change of 0.52 this illustrates that the inclusion of 3 interaction terms causes $\mathrm{R}^{2}$ change of $5.2 \%$ (added variance).

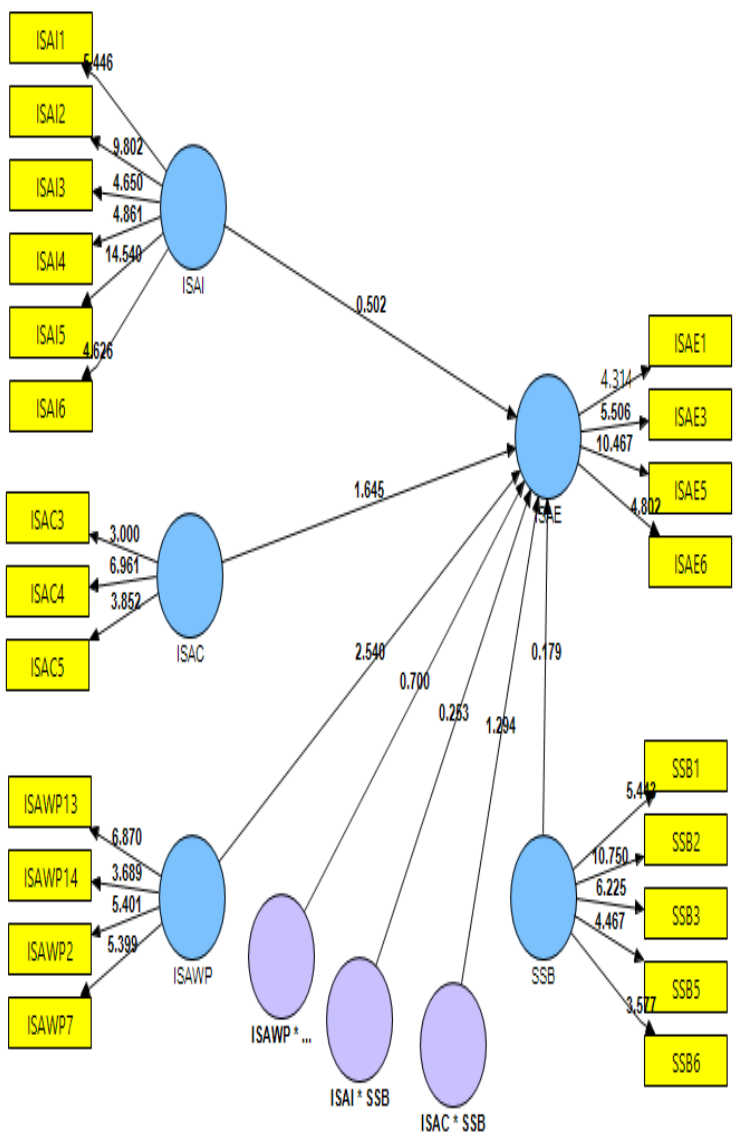

Figure 3. The $\mathrm{R}^{2}$ interaction effect model

ISAI: Internal Shariah Audit Independence

ISAC: Internal Shariah Audit Competency

ISAWP: Internal Shariah Audit Work Performance

ISAE: Internal Shariah Audit Effectiveness

SSB: Shariah Supervisory Board

\section{Discussion and Conclusion}

\subsection{Theoretical Implications}

This paper contributes to Islamic accountability theory in its quest of exploring factors influencing an effective internal Shariah audit in Bahrain's IFIs. Hence, the research model of this paper is concurred. Its contribution to the current literature is providing empirical proof pertaining to the standards of AAOIFI. It also provides information to the IFIs' stakeholders. Additionally, the questionnaire developed by this study has been adapted from AAOIFI (2010) based on literature review. As previously discussed, studies done on internal Shariah audit that is effective are scarce. This kind of study is quite urgent to nations that are experiencing emerging and transitional economies. Therefore, as the result of the scarcity of study in this area, the study makes a contribution to internal Shariah audit's area of research. For the study's purpose, survey questionnaire had been used for collection of data. Thus, this study's quantitative data contribute towards the understanding of internal Shariah audit that is effective. This study further 
contribution is its exploration of the execution of internal Shariah audit in growing economies like Bahrain.

Currently, the internal Shariah auditing is disorganized. This study indicates the pressing need of IFIs in having a structured framework for internal Shariah audit. The availability of guideline can result in better structure of this type of auditing. It can also consequently result in enhanced structured report for the presentation to IFIs' shareholders in enhancing their confidence. Rahman (2008) states that there is a need for Shariah audit to strengthen shareholders' confidence that IFIs' activities and operations follow the Shariah guidelines.Moreover, an effective audit, in which its Shariah auditors are competent, contribute to Islamic accountability theory. This is because the practitioners of Islamic banking have understood their accountability to Allah s.w.t in distinguishing the characteristics IFIs from that of traditional banking system. Additionally, the auditors of internal Shariah audit are also answerable to the Allah s.w.t and company's stockholders in its assessment. Hence, the support by SSB and board of directors is crucial. The study's results are also beneficial for future studies of such nature.

\subsection{Practical Implications}

This research is the pioneer in exploring factors that cause a successful and meaningful internal Shariah auditing among Bahrain's IFIs. Additionally, this study has discovered that to attain that goal, factors such as being competent and the performance in planning and executing of tasks, and communicating of audit outcomes are crucial.

This study also proposes on the avenues in regard to the governance function of SSB; in which the internal Shariah audit operates including the auditing of SSB's Shariah decisions. Based on the benchmarks of AAOIFI, the strengthening of SSB members' independence should be considered. Similar to the Bank Negara Malaysia (BNM)'s Shariah governance framework (SGF), it is proposed that the recommendation of SSB members' appointment to come from the IFI's BOD, and agreed by Bank Negara Malaysia. Meanwhile, the SSB's size in terms of its members should also exceed five (5) persons, and majority of them must have strong Shariah knowledge with relevant qualification. This method of appointment will ensure that SSB is held accountable for its actions, and possess a reporting method to shareholders. Additionally, it is the current practice that SSB members being appointed based on their experience, and not on their proficiency in Islamic finance.

Currently, the IFIs adopt many types of Shariah audit practices. For example, certain IFIs have their own Shariah audit department, others outsource this function, whilst other IFIs execute Shariah reviews. From the analyses of financial and non-financial reports of Bahrain's major IFIs, we found that majority of them undertook a Shariah review instead of Shariah audit. In matters pertaining to audit, only a small percentage of them stated that the function is given to the compliance department related to Shariah (Shafii et al., 2015). The lack of dedicated Islamic financing training organizations in Bahrain has contributed to the shortage of SSB experts. This can only be resolved through the investments made by CBB and AAOFI in education and professional facilities. This action will allow Bahrain to follow Malaysia's footsteps in establishing institutions that offer Islamic finance courses. Consequently, this will facilitate the SSB's operation in Bahrain's IFIs, as well as worldwide. This solution is to improve SSB's establishment as the legal guardian to IFIs' Shariah where established sets of guidelines are issued to monitor itself and others. It is obvious the AAOIFI benchmarks have great impact on IFIs, and it is proposed that such standards be implemented (Farook and Farooq, 2011).

The study's results illustrate that to sustain the technical expertise of Shariah auditors, IFIs need to further invest in their education and training. This will improve the investors and stakeholders' confidence. As for work performance, more investigations are needed to be undertaken on the adequacy and effectiveness of IFIs in executing SSB's fatwas, guidelines and directives. Written program of internal Shariah audit, suitable timeframe, determination of resources as well as communication are elements in improving the internal Shariah audit's work performance. This study also proposes that the audit personnel be sent for training and obtain a professional certification. This certification is to cover the Shariah audit area as stated by AAOIFI, as well as policies, processes and procedures, calculation and payment of Zakah, and contracts.

More importantly, Bahrain is unique in which it is experiencing a very rapid development, and has associations and bodies such as AAOIFI, CIBAFI; and international Islamic finance hubs of LMF, IIFM and IIRA that make the role of internal Shariah audit relevant. Moreover, response bias may be present. This is because the IFIs' head of internal Shariah audit are the respondents. Moreover, in view that this study's implication is also about these auditors' independence, we propose that the Shariah audit department must undertake the Shariah auditing tasks themselves for them to be viewed as independent.

Additionally, the report prepared by internal Shariah auditors must be made to the BOD in reducing the 
self-appraisal issue. Nonetheless, this study discovered that certain IFIs adopt Shariah review instead of Shariah audit. Here, the Shariah review is done by the SSB, and audit functions are given to the internal Shariah compliance unit. When compared with other nations like Malaysia, internal auditors are to conduct Shariah audit, and these auditors must possess the related certification. This study proposes that as the regulatory body of Bahrain's IFIs, AAOIFI benchmarks must outline the establishment of new roles and regulations so that the internal Shariah audit department can be more efficient and effective. The study's practical implication for all variables are similar to AAOIFI benchmark (2010).

\subsection{Limitations of the Study}

Firstly, this study's sample size was 52 IFIs. Despite these institutions being representatives of the population, larger sample size may allow the examination of more variables.

Secondly, this study concentrates only on the examined attributes (i.e. independent, competent and performance) for an effective internal Shariah audit. This is because the literature related to this field is quite scarce.

\subsection{Suggestions for Future Research}

In view that this study only consisted of Bahrain's 52 IFIs, future research may want to include those Islamic financial institutions of Gulf countries council (GCC) and conduct a comparative study on this area. They may also include other variables such as IFI's audit department size, cooperation between the internal and external auditors, as well as support to internal auditors by the management. This study has discovered that the examined attributes of internal Shariah auditors and SSB explain $63.2 \%\left(\mathrm{R}^{2}=0.632\right)$ of the variance.

This signifies that those three independent variables and moderator variable contribute $63.2 \%$ to the dependent variable; and other factors contribute $36.8 \%$. The other factors not being explored by this study are the magnitude of internal Shariah audit unit, cooperation between internal and external auditors, backing received from the management and internal Shariah audit's scope. It is vital that future research explore the linkages of internal Shariah audit and auditors' views on Shariah audit effectiveness. To attain adequate freedom, the internal Shariah auditors must directly interact, report and discuss with the board of directors instead of the CEO. These actions will ensure the auditors their independence and credibility. They must be able to express their opinions independently and report on any irregularities without the consent of the CEO, and without prejudice and limitations.

Finally, more studies are needed in examining the moderator role of SSB. Hence, this study's research model is supported. This study's contribution is the presentation of empirical data related to AAOIFI benchmarks. This study also provides the information to IFIs' stakeholders. Based on study's findings, it can be said that examined factors are significant for an effective internal Shariah audit. Nonetheless, support from the IFIs' management and shareholders is vital for a better and meaningful audit.

\section{References}

Aaoifi. (2010). Accounting, Auditing And Governance Standards For Islamic Financial Institution. Manama, Bahrain

Ahmad, N., Othman, R., Othman, R., \& Jusoff, K. (2009). The Effectiveness Of Internal Audit In Malaysian Public Sector. Journal of Modern Accounting And Auditing, 5(9), 53.

Ali, A., Gloeck, J., Ali, A., Ahmi, A., \& Sahdan, M. (2007). Internal Audit in the State and Local Governments of Malaysia. Southern African Journal of Accountability and Auditing Research, 25-57.

Alkdai, H. K. H., \& Hanefah, M. M. (2012). Audit Committee Characteristics And Earnings Management In Malaysian Shariah-Compliant Companies. Business And Management Review, 2, 52-61.

Al-Twaijry, A. A., Brierley, J. A., \& Gwilliam, D. R. (2003). The Development Of Internal Audit In Saudi Arabia: An Institutional Theory Perspective. Critical Perspectives on Accounting, 14, 507-531. https://doi.org/10.1016/S1045-2354(02)00158-2

Alzeban, A., \& Gwilliam, D. (2014). Factors Affecting the Internal Audit Effectiveness: A Survey of the Saudi Public Sector. Journal of International Accounting, Auditing and Taxation, 23(2), 74-86. https://doi.org/10.1016/j.intaccaudtax.2014.06.001

Arena, M., \& Azzone, G. (2009). Identifying Organizational Drivers of Internal Audit Effectiveness. International Journal of Auditing, 13(1), 43-60. https://doi.org/10.1111/j.1099-1123.2008.00392.x

Badara, M. A. S., \& Saidin, S. Z. (2014). Empirical Evidence Of Antecedents Of Internal Audit Effectiveness From Nigerian Perspective. Middle-East Journal of Scientific Research, 19(4), 460-471. 
Chin, W. W., Marcolin, B. L., \& Newsted, P. R. (2003). A Partial Least Squares Latent Variable Modeling Approach For Measuring Interaction Effects: Results From A Monte Carlo Simulation Study And An Electronic-Mail Emotion/Adoption Study. Information Systems Research, 14, 189-217. https://doi.org/10.1287/isre.14.2.189.16018

Davies, M. (2009). Effective Working Relationships Between Audit Committees And Internal Audit - The Cornerstone Of Corporate Governance In Local Authorities, A Welsh Perspective. Journal of Management \& Governance, 13, 41-73. https://doi.org/10.1007/s10997-008-9070-9

Duarte, P. A. O., \& Raposo, M. L. B. (2010). A Pls Model to Study Brand Preference: An Application to the Mobile Phone Market. Handbook Of Partial Least Squares. Springer. https://doi.org/10.1007/978-3-540-32827-8_21

Endaya, K. A., \& Hanefah, M. M. (2013). Internal Audit Effectiveness: An Approach Proposition to Develop the Theoretical Framework. Research Journal of Finance and Accounting, 4(10), 92-102.

Farook, S. Z., \& Farooq, M. O. (2011). Shariah Governance For Islamic Finance: Challenges And Pragmatic Solutions. SSRN. https://doi.org/10.2139/ssrn.1813483

Farook, S., Hassan, M. K., \& Lanis, R. (2011). Determinants Of Corporate Social Responsibility Disclosure: The Case Of Islamic Banks. Journal of Islamic Accounting And Business Research, 2, 114-141. https://doi.org/10.1108/17590811111170539

Fornell, C., \& Larcker, D. F. (1981). Evaluating Structural Equation Models With Unobservable Variables And Measurement Error. Journal of Marketing Research, 39-50. https://doi.org/10.1177/002224378101800104

Fowler, F. J. (2009). Survey Research Methods. Sage. https://doi.org/10.4135/9781452230184

Getie Mihret, D., \& Wondim Yismaw, A. (2007). Internal Audit Effectiveness: An Ethiopian Public Sector Case Study. Managerial Auditing Journal, 22, 470-484. https://doi.org/10.1108/02686900710750757

Goodwin-Stewart, J., \& Kent, P. (2006). The Use Of Internal Audit By Australian Companies. Managerial Auditing Journal, 21, 81-101. https://doi.org/10.1108/02686900610634775

Grais, W. M., \& Pellegrini, M. (2006). Corporate Governance In Institutions Offering Islamic Financial Services: Issues and Options. https://doi.org/10.1596/1813-9450-4052

Hair, J. F., Ringle, C. M., \& Sarstedt, M. (2011). Pls-Sem: Indeed a Silver Bullet. Journal of Marketing Theory and Practice, 19(2), 139-152. https://doi.org/10.2753/MTP1069-6679190202

Hair, J., Anderson, R., Tatham, R., \& Black, W. (2010). Multivariate Data Analysis. New Jersey: Pearson Prentice Hall

Hameed, S., \& Mulyany, R. (2009). Shariah Audit for Islamic Financial Institutions (Ifis): Perceptions of Accounting Academicians, Audit Practitioners and Shariah Scholars.

Haron, H., Jantan, M., \& Pheng, E. G. (2005). Audit Committee Compliance With Kuala Lumpur Stock Exchange $\begin{array}{lllll}\text { Listing } & \text { Requirements. International Journal of Auditing, 9, 187-200. }\end{array}$ https://doi.org/10.1111/j.1099-1123.2005.00256.x

Hood, K., \& Bucheery, R. (1999). The Interaction Of Religious (Islamic) Auditors With Reference To The Audit Expectation Gap In Bahrain. Accounting, Commerce And Finance: The Islamic Perspective Journal, 3(1), 25-28.

Iqbal, M., \& Molyneux, P. (2005). Thirty Years Of Islamic Banking: History, Performance, And Prospects. https://doi.org/10.1057/9780230503229

Karim, R. A. A. (1990). The Independence Of Religious And External Auditors: The Case Of Islamic Banks. Accounting, Auditing \& Accountability Journal, 3. https://doi.org/10.1108/09513579010004097

Kasim, N., Ibrahim, M., Hameed, S., \& Sulaiman, M. (2009). Shariah Auditing In Islamic Financial Institutions: Exploring The Gap Between The "Desirable" And The "Actual". Global Economy \& Finance Journal, 2, 127-137.

Khan, M. A. (1982). Al-Hisba And The Islamic Economy. Ibn Taymiya, Public Duties in Islam, 135-151.

Mihret, D. G., \& Yismaw, A. W. (2007). Internal Audit Effectiveness: An Ethiopian Public Sector Case Study. Managerial Auditing Journal, 22(5), 470-484. https://doi.org/10.1108/02686900710750757

Mulyany, R. (2008). Shariah Ausit for Islamic Financial Institutions: Perception of Accounting Academicians, Audit 
Practitioners, and Shariah Scholars. Master of Science in Accounting, International Islamic University Malaysia.

Najeeb, S. F., \& Ibrahim, S. H. M. (2014). Professionalizing The Role Of Shari'ah Auditors: How Malaysia Can Generate Economic Benefits. Pacific-Basin Finance Journal, 28, 91-109. https://doi.org/10.1016/j.pacfin.2013.10.009

Nasibah, A., Othman, R., Othman, R., \& Jusoff, K. (2009). The Effectiveness Of Internal Audit In Malaysian Public Sector. Journal Of Modern Accounting And Auditing, 5, 53.

Nunnally, J. C., \& Bernstein, I. (1994). The Assessment Of Reliability. Psychometric Theory, 3, 248-292.

Othman, R., Ameer, R., \& Choudhury, M. (2015). Conceptualizing The Duties And Roles Of Auditors In Islamic Financial Institutions: What Makes Them Different?. Humanomics, 31. https://doi.org/10.1108/H-04-2013-0027

Qattan, M. A. (2003). Shariah Supervision: The Unique Building Block Of Islamic Financial Architecture. Islamic Financial Architecture, 273.

Rahman, A. (2008). Shari'ah Audit For Islamic Financial Services: The Needs And Challenges. Paper Presented At The Isra Islamic Finance Seminar, Mandarin Hotel, Kuala Lumpur.

Rahman, A. R. A. (2011). Enhancing the Integrity of Islamic Financial Institutions in Malaysia: The Case for the Shariah Audit Framework. Isra International Journal of Islamic Finance, 3(1), 135-147.

Sarea, A. M. (2012). The Level of Compliance With Aaoifi Accounting Standards: Evidence From Bahrain. International Management Review, 8(2), 27.

Sarea, A. M., \& Hanefah, H. M. M. (2013). The Need Of Accounting Standards For Islamic Financial Institutions. International Management Review, 9(2), 50.

Shafii, Z., Abidin, A. Z., \& Salleh, S. (2015). Integrated Internal-External Shariah Audit Model: A Proposal Towards the Enhancement of Shariah Assurance Practices in Islamic Financial Institutions. Jeddah: Islamic Research and Training Institute.

Sharma, V. D., Sharma, D. S., \& Ananthanarayanan, U. (2011). Client Importance and Earnings Management: The Moderating Role of Audit Committees. Auditing: A Journal of Practice \& Theory, 30(3), 125-156. https://doi.org/10.2308/ajpt-10111

Soh, D. S., \& Martinov-Bennie, N. (2011). The Internal Audit Function: Perceptions of Internal Audit Roles, Effectiveness and Evaluation. Managerial Auditing Journal, 26, 605-622. https://doi.org/10.1108/02686901111151332

Turley, S., \& Zaman, M. (2007). Audit Committee Effectiveness: Informal Processes And Behavioural Effects. Accounting, Auditing \& Accountability Journal, 20, 765-788. https://doi.org/10.1108/09513570710779036

Yaacob, H., \& Donglah, N. K. (2012). Shari'ah Audit in Islamic Financial Institutions: The Postgraduates' Perspective. International Journal of Economics and Finance, 4(12), 224. https://doi.org/10.5539/ijef.v4n12p224

Yahya, Y., \& Mahzan, N. (2012, March 12-13). The Role Of Internal Auditing In Ensuring Governance In Islamic Financial Institution (Ifi). 3rd International Conference On Business And Economic Research (3rd Icber 2012). Golden Flower Hotel, Bandung, Indonesia. 